\title{
Differences in the trophic role of Mysis diluviana in two intermontane lakes
}

\author{
John D. Whall ${ }^{1}$, David C. Lasenby ${ }^{2, *}$ \\ ${ }^{1}$ Watershed Ecosystems Program, and ${ }^{2}$ Department of Biology, Trent University, 1600 West Bank Drive, Peterborough, \\ Ontario K9J 7B8, Canada
}

\begin{abstract}
The trophic role of the freshwater shrimp Mysis diluviana was compared between 2 neighbouring lakes in British Columbia to investigate its possible role in the collapse of the Okanagan Lake kokanee salmon Oncorhynchus nerka population. Stable isotopes of nitrogen $\left(\delta^{15} \mathrm{~N}\right)$ and carbon $\left(\delta^{13} \mathrm{C}\right)$ were used to compare the trophic relationships of mysids within the pelagic food web and between lakes. Mid-summer $\delta^{15} \mathrm{~N}$ signatures suggested that adult mysids in Okanagan Lake were acting more as primary consumers, and Kalamalka Lake mysids were acting as secondary consumers. M. diluviana's predatory capacity was also assessed through in situ clearance rate feeding experiments and examination of gut contents. $M$. diluviana $<1 \mathrm{yr}$ old in Okanagan Lake were capable of clearing a greater volume of prey, but there was no difference between lakes for M. diluviana $>1$ yr old. Gut contents confirmed $M$. diluviana in both lakes were consuming copepod and cladoceran prey. All 3 techniques demonstrated ontogenetic diet shifts, with larger mysids obtaining more energy from zooplankton prey. Although mysids in feeding experiments actively consumed the same zooplankton prey as kokanee, $\delta^{15} \mathrm{~N}$ and $\delta^{13} \mathrm{C}$ ratios suggest that mysids in Okanagan Lake were not feeding at the same trophic level as kokanee, which indicates that there may have been less competition for food sources than previously thought. These differences in results suggest that predatory capacity, as indicated by in situ feeding experiments or gut content analysis, should not be used in isolation to establish trophic roles for omnivorous animals.
\end{abstract}

KEY WORDS: Mysis relicta $\cdot$ Mysis diluviana $\cdot$ Stable isotopes · Trophic position · Okanagan Lake · Clearance rates

Resale or republication not permitted without written consent of the publisher

\section{INTRODUCTION}

The role of the opossum shrimp Mysis diluviana (formerly M. relicta; Audzijonyte \& Väinölä 2005) in the decline of native planktivorous fish stocks in lakes into which it has been introduced is well documented. In particular, predation by $M$. diluviana on zooplankton has been implicated in the elimination or temporal displacement of cladoceran populations and subsequent disruption of energy flow to planktivorous fishes (Lasenby et al. 1986, Bowles et al. 1991, Martinez \& Bergersen 1991, and others). As mysids increase the length of food chains in their native glacial-relict lakes through their omnivorous feeding habits (Sprules \& Bowerman 1988), their introduction into non-glacial food webs may effectively increase the number of trophic linkages in the new system. The consumption of lower trophic levels by introduced $M$. diluviana may divert food resources that were previously available to the native planktivorous fish.

In North American intermontane lakes where Mysis diluviana has been introduced, significant population reductions of kokanee salmon Oncorhynchus nerka have been documented (Morgan et al. 1978, Beattie \& Clancey 1991, Ashley et al. 1997, Spencer et al. 1999). Kokanee are planktivorous forage fish that play a key role in energy transfer to piscivorous fish such as lake trout Salvelinus namaycush, and they can provide an economically valuable sportfishery. It has been assumed that $M$. diluviana has a similar trophic role and competes with kokanee for food. However, in 2 neighbouring lakes in British Columbia, Okanagan 
and Kalamalka Lakes, where mysids were introduced in the 1960s, kokanee populations have responded quite differently to the introduction of $M$. diluviana.

Since the mid-1980s, Okanagan Lake has undergone a significant loss of kokanee stocks, which forced the closure of the sportfishery for this species in 1995 (Ashley et al. 1997), whereas neighbouring Kalamalka Lake is able to support a viable kokanee population and sportfishery. Acoustic surveys of both lakes in 1996-1997 suggested that kokanee densities in Kalamalka Lake ( 700 fish ha ${ }^{-1}$ ) were approximately 3.5 times higher than in Okanagan Lake ( 200 fish ha $\left.{ }^{-1}\right)$ (Sebastian \& Scholten 1998). A prominent theory regarding the loss of kokanee in Okanagan Lake is that the introduced Mysis diluviana were outcompeting these planktivorous forage fish for pelagic zooplankton (Ashley et al. 1998). However, zooplankton abundance does not appear to account for the sustained Kalamalka Lake kokanee fishery. Average total zooplankton densities remained similar between the 2 lakes during the 1996 to 1998 sampling seasons, ranging from 1.2 to 2.8 ind. $\mathrm{l}^{-1}$ (McEachern 1999). The proportion of cladocerans, which are the preferred food source for kokanee, was only slightly higher in Kalamalka Lake ( $\sim$ to $8 \%$ of total zooplankton) than in Okanagan Lake ( $\sim 3 \%$ of total) (McEachern 1999). In addition, mean population estimates for $M$. diluviana from deep sampling stations were greater in Kalamalka Lake (418 \pm 43 ind. $\left.{ }^{-2}\right)$ than in Okanagan Lake $\left(300 \pm 24\right.$ ind. $\left.\mathrm{m}^{-2}\right)$ over the same sampling period (Whall 2000). Therefore, the loss of kokanee stocks in Okanagan Lake is unlikely to be due to mysid population impacts on zooplankton abundance alone. A possible explanation for the difference in kokanee abundance in the 2 lakes could be that the mysids have different trophic roles in the 2 lakes and are competing less or not at all with kokanee for food in Kalamalka Lake.

Mysis diluviana is omnivorous and goes through ontogenetic shifts in its diet, becoming more predatory with increasing age (Branstrator et al. 2000). This life history adaptability improves the success of young mysids born early in the summer, when zooplankton abundance is minimal (Naesje et al. 2003), and could lead to variability in mysid trophic position between lakes. We hypothesized that if $M$. diluviana were diverting a significantly greater proportion of the zooplankton prey resources from the planktivorous fish communities in Okanagan Lake than Kalamalka Lake, then mysids in Okanagan Lake would be incorporating a greater proportion of zooplankton in their diet, relative to mysids in Kalamalka Lake.

We examined the pelagic feeding habits of Mysis diluviana and its trophic role in the 2 lakes using the trophic position model of food web structure (Vander Zanden \& Rasmussen 1996, Post 2002). This model pro- vides a continuous estimate of energy transfer from primary producer to top consumer by tracking relative differences in stable isotopes $\left(\delta^{15} \mathrm{~N}\right.$ and $\left.\delta^{13} \mathrm{C}\right)$ between prey and predators within the food web. The model is especially useful for understanding energy transfers for omnivorous animals, such as $M$. diluviana, that do not belong to a rigid trophic guild. To provide supporting evidence for the stable isotope analyses and confirm $M$. diluviana's pelagic feeding habits in the 2 lakes, we also examined $M$. diluviana's gut contents and compared prey removal rates in the 2 lakes.

\section{MATERIALS AND METHODS}

Study lakes. Okanagan Lake $\left(50^{\circ} 14^{\prime} \mathrm{N}, 119^{\circ} 21^{\prime} \mathrm{W}\right.$; $\left.351 \mathrm{~km}^{2}, z_{\max }=242 \mathrm{~m}\right)$ and Kalamalka Lake $\left(50^{\circ} 14^{\prime} \mathrm{N}\right.$, $119^{\circ} 16^{\prime} \mathrm{W} ; 26 \mathrm{~km}^{2}, z_{\max }=142 \mathrm{~m}$ ) are the largest of the Okanagan Drainage Basin lakes located in the southcentral interior of British Columbia. Both are oligotrophic steep-sided valley lakes with narrow littoral zones (Andrusak 2000).

Specimen collections and experiments outlined in the methods below were carried out in both lakes within days of each other, unless otherwise indicated.

Stable isotope analysis and food web structure. Samples for stable isotope analysis were obtained in August 1997 and June 1998. Food web energy linkages were explored between sediment, phytoplankton, benthos, zooplankton, mysids and fish.

As mysids feed on lake sediment (Johannsson et al. 2001, Lasenby \& Shi 2004), representative samples were obtained from a depth of $15 \mathrm{~m}$ in August 1997 using an Ekman dredge, and from a depth of $70 \mathrm{~m}$ in June 1998 using a K-B corer (Wildlife Supply Company). When using the K-B corer, the top $1 \mathrm{~cm}$ of sediment was siphoned off and collected using water from the sediment-water interface. All sediment was sifted through a $500 \mu \mathrm{m}$ mesh nylon screen, collected in sterile $250 \mathrm{ml}$ plastic bags and stored on ice until rinsed with $10 \% \mathrm{HCl}$ and distilled deionized water $\left(\mathrm{ddH}_{2} \mathrm{O}\right)$ (Estep \& Vigg 1985, Keough et al. 1996). The water/sediment slurries were then collected on $1 \mu \mathrm{m}$ Gelman GF/F discs that had been precombusted at $400^{\circ} \mathrm{C}$ for $2 \mathrm{~h}$. Sediment was then removed from the filter and dried at $60^{\circ} \mathrm{C}$ in preacid-rinsed borosilicate glass vials for a minimum of $72 \mathrm{~h}$.

Particulate organic matter (POM), consisting mainly of phytoplankton (Kling et al. 1992), was assumed to form the base of the food chain for pelagic primary consumers, and may serve as a food source for mysids. To isolate POM from the metalimnion, which was the depth at which mysids fed during the night (Whall 2000), water was collected using a submersible pump, then filtered (64 $\mu \mathrm{m}$ mesh) and stored in 201 opaque plastic carboys. POM was filtered from the stored 
water within $2 \mathrm{~h}$ by passing the sample through a $1 \mu \mathrm{m}$ $\mathrm{GF} / \mathrm{F}$ in-line $47 \mathrm{~mm}$ diameter filter disc to obtain isotope signatures for POM in the 1 to $64 \mu \mathrm{m}$ size range. Following filtration, POM on the $1 \mu \mathrm{m}$ GF/F filters was rinsed with $10 \% \mathrm{HCl}$, rinsed again with $\mathrm{ddH}_{2} \mathrm{O}$ and then dried at $60^{\circ} \mathrm{C}$ for a minimum of $72 \mathrm{~h}$.

Zooplankton was collected from $30 \mathrm{~m}$ depth to the surface using a Wisconsin plankton net and sorted by size fraction $(295,210,110$ and $64 \mu \mathrm{m})$ using a series of nylon mesh sieves. Each size fraction was then concentrated and transferred to $64 \mu \mathrm{m}$ filtered metalimnetic water. Zooplankton were kept alive on ice until separated by taxa, then rinsed with $10 \% \mathrm{HCl}$, placed in $5 \mathrm{ml}$ glass vials and dried. A minimum of 500 individuals of Daphnia spp. and calanoid and cyclopoid copepods were isolated from the 295 and $210 \mu \mathrm{m}$ fractions for analysis.

Mysids were collected from deep-water stations (>100 m depth) between 23:00 and 01:00 h, during their nighttime vertical feeding migration into the metalimnion. Hauls were made with a $1 \mathrm{~m}^{2}$ Wisconsin plankton net from $\sim 2 \mathrm{~m}$ off the bottom to the surface. Mysids were placed in pre-filtered $(64 \mu \mathrm{m})$ metalimnetic water and sorted according to size: small juveniles born that year (Year 0), intermediate immature animals (late Year 0 or early Year 1 cohorts) and large adults (mature Year 1 cohort); 10 to 15 animals of each class were measured to the nearest $0.1 \mathrm{~mm}$, rinsed with $10 \% \mathrm{HCl}$ and $\mathrm{ddH}_{2} \mathrm{O}$ and dried in glass vials.

Kokanee, lake trout, rainbow trout Oncorhynchus mykiss and whitefish Coregonus clupeaformis samples were obtained from both Okanagan and Kalamalka Lakes to show possible food web linkages for potential predators of mysids. Samples were provided by the BC Ministry of Environment, Lands and Parks (MELP). In all cases, fish had been frozen intact within a few hours of being caught. Muscle tissue samples $\left(\sim 1 \mathrm{~cm}^{3}\right)$ were extracted from just behind the operculum and above the lateral line. All skin, scales, subcutaneous adipose tissue and bones were removed from the samples. The remaining sections of tissue were rinsed with $\mathrm{ddH}_{2} \mathrm{O}$, placed in glass vials and dried at $60^{\circ} \mathrm{C}$.

With the exception of zooplankton (which was scraped from the sides of the glass containers), all samples were homogenized using a porcelain mortar and pestle, transferred to ultra clean aluminum foil weighing capsules, weighed to the nearest $0.0001 \mathrm{mg}$ and sealed for analysis. Blank GF/F discs were also prepared for analysis by rinsing with $10 \% \mathrm{HCl}$ and $\mathrm{ddH}_{2} \mathrm{O}$ before drying.

Triplicate samples of each homogenized sample type were analyzed using a Finnigan-Mat continuous flowisotope ratio mass spectrometer (CF-IRMS) to determine $\delta^{15} \mathrm{~N}$ and $\delta^{13} \mathrm{C}$. Analytical precision was $\pm 0.3 \%$ for $\delta^{15} \mathrm{~N}$ and $\pm 0.1 \%$ for $\delta^{13} \mathrm{C}$ (G. St. Jean pers. comm.). Standard errors around triplicate samples of the same homogenized material were $\leq 0.2 \%$ for $\delta^{15} \mathrm{~N}$ and $\delta^{13} \mathrm{C}$ signatures of food web organisms.

Isotope ratios of tissue samples were determined as:

$\delta^{15} \mathrm{~N}$ or $\delta^{13} \mathrm{C} \%=\left[\left(\mathrm{R}_{\text {sample }}-\mathrm{R}_{\text {standard }}\right)\left(\mathrm{R}_{\text {standard }}\right)^{-1}\right] 1000$

where $\mathrm{R}$ is the ratio of ${ }^{15} \mathrm{~N} /{ }^{14} \mathrm{~N}$ or ${ }^{13} \mathrm{C} /{ }^{12} \mathrm{C}$, 'sample' is the tissue sample analyzed, and 'standard' are the international standards of VPDB limestone (for $\delta^{13} \mathrm{C}$ ) and $\mathrm{N}_{\text {air }}$ (for $\delta^{15} \mathrm{~N}$ ) (Fry 1991).

Trophic positions (TP) of consumers were determined from an assumed $\delta^{15} \mathrm{~N}$ difference of $3.4 \%$ between predator and prey (Minagawa \& Wada 1984, Wada et al. 1993, Cabana \& Rasmussen 1994, Vander Zanden et al. 1997, Post 2002), with the first trophic position being equal to the $\delta^{15} \mathrm{~N}$ signature of phytoplankton in the lake:

$\mathrm{TP}_{\text {consumer }}=\left[\left(\delta^{15} \mathrm{~N}_{\text {consumer }}-\delta^{15} \mathrm{~N}_{\text {phytoplankton }}\right)+1\right] 3.4^{-1}$

To determine which proportion of the mysid diet was made up of benthic sediment organic material versus planktonic (e.g. phyto- and zooplankton) sources, the relative amounts of benthic and pelagic carbon $\left(\delta^{13} \mathrm{C}\right)$ assimilated by the mysids were determined using a 2-source mixing model modified from Vander Zanden \& Rasmussen (2001):

$\%$ Benthic carbon $=\left[\left(\delta^{13} \mathrm{C}_{\text {mysid }}-\mathrm{TP}_{\text {mysid }} \times 0.47-\delta^{13} \mathrm{C}_{\text {pelagic }}\right)\right.$

and

$$
\left.\left(\delta^{13} C_{\text {benthic }}-\delta^{13} C_{\text {pelagic }}\right)^{-1}\right] 100
$$

\% Pelagic carbon = $100-\%$ Benthic carbon

where $\delta^{13} \mathrm{C}_{\text {mysid }}$ is the mean ${ }^{13} \mathrm{C} /{ }^{12} \mathrm{C}$ ratio for Mysis diluviana, $\delta^{13} \mathrm{C}_{\text {benthic }}$ the mean ${ }^{13} \mathrm{C} /{ }^{12} \mathrm{C}$ ratio for sediments, $\delta^{13} \mathrm{C}_{\text {pelagic }}$ the mean ${ }^{13} \mathrm{C} /{ }^{12} \mathrm{C}$ ratio for POM and pelagic zooplankton, $\mathrm{TP}_{\text {mysid }}$ the trophic position estimate for $M$. diluviana (assumed to be 1.0 relative to mean pelagic and benthic carbon sources) and 0.47 the average $\delta^{13} \mathrm{C}$ fractionation factor between predator and prey (including herbivores), as described in Vander Zanden \& Rasmussen (2001). The trophic position correction factor (i.e. $\mathrm{TP}_{\text {mysid }} 0.47$ ) was added to the model to account for expected fractionation of carbon isotope ratios due to trophic transfer.

Mysid gut contents. To verify prey items in the diet of mysids in the 2 lakes, mysids were collected in August 1997 from the meta- and epilimnia at 04:00 h at the end of the diurnal migration cycle. Stomachs of 10 mysids from each of Year 0 and Year 1 cohorts were extracted, placed on a glass microscope slide in a drop of glycerine, teased apart and viewed under $100 \times$ magnification. Rotifer genera and zooplankton mandible type (calanoid, cyclopoid, Daphnia spp. and Diaphanasoma spp.) were enumerated for each stomach.

Mysid clearance rate experiments. To support stable isotope evidence for mysid diet and determine if mysid predation on zooplankton was similar between lakes, 
we conducted clearance rate experiments during June and August 1997. In these controlled feeding experiments, mysids were offered a natural zooplankton assemblage from their respective lakes.

For each trial, mysids were collected at night and held in unfiltered metalimnetic water for $24 \mathrm{~h}$. Approximately $3 \mathrm{~h}$ prior to the experiment, all mysids were transferred to filtered (64 $\mu \mathrm{m}$ mesh) metalimnetic water to avoid introducing any additional zooplankton to the feeding chambers. Translucent 201 polyethylene plastic containers filled with filtered metalimnetic water were used for feeding chambers; 5 containers contained zooplankton only (controls), 5 contained 10 small Year 0 cohort mysids and zooplankton, and 5 contained 10 large Year 1 cohort mysids and zooplankton. Zooplankton was collected by taking multiple vertical hauls through the metalimnion using a Wisconsin closing net (120 $\mu \mathrm{m}$ mesh). Zooplankton was placed in filtered metalimnetic water and randomly transferred to feeding chambers at densities approximating those found within each lake. Mysids were then added to the experimental chambers and suspended in the metalimnion for approximately $8 \mathrm{~h}$, after which the chambers were retrieved and the contents of each was filtered through a $64 \mu \mathrm{m}$ mesh and preserved in $95 \%$ ethanol for zooplankton identification and enumeration. Mysids from each chamber were measured to the nearest $0.1 \mathrm{~mm}$.

Mysid clearance rates, $F\left(\mathrm{ml} \mathrm{mysid}^{-1} \mathrm{~h}^{-1}\right)$, were calculated for each zooplankton taxon found and for the total zooplankton assemblage present as follows:

$$
F=\left[1000 V \times \ln \left(C Z^{-1}\right)\right](t n)^{-1}
$$

where $V$ is the chamber volume (1), $C$ the prey concentration in the control chamber remaining at the end of the experiment, $Z$ the prey concentration in the experimental chamber remaining at the end of the experiment, $t$ the time spent feeding (h) and $\mathrm{n}$ the number of mysids in the chamber (modified from Bowers \& Vanderploeg 1982).

Statistical analyses. Mysid isotope signatures and clearance rates were compared conducted using 1-way ANOVA. Trophic position estimates for individual size classes of mysids were compared between lakes using Student's $t$-test. All statistical analyses were conducted using SigmaStat computer software.

\section{RESULTS}

\section{Mysid trophic position and food web structure from stable isotopes}

Stable isotope ratios $\left(\delta^{15} \mathrm{~N}\right.$ and $\left.\delta^{13} \mathrm{C}\right)$ for all members of the food webs sampled are presented in Table 1. POM, which forms the base of the pelagic food web, had very similar $\delta^{15} \mathrm{~N}$ values between lakes, indicating little difference in pelagic nitrogen sources between lakes for the higher trophic levels. In both lakes, POM was a key food source for Daphnia spp., which were enriched by 1.8 to $4.8 \%{ }^{15} \mathrm{~N}$ and 0.6 to $1.6 \%{ }^{13} \mathrm{C}$ relative to POM (insufficient quantities of Daphnia spp. were available for a sample in Okanagan Lake in June 1998). Copepods were between 2.8 and $3.9 \%$ more enriched in $\delta^{15} \mathrm{~N}$ than Daphnia spp., although they maintained similar $\delta^{13} \mathrm{C}$ signatures, indicating that they were feeding approximately about 1 trophic level above Daphnia spp. Bulk zooplankton collections showed increasing nitrogen enrichment and carbon depletion with increasing size fractions. Zooplankton collections from Kalamalka Lake were enriched by up to $3.8 \%$ in $\delta^{15} \mathrm{~N}$ relative to those in Okanagan Lake.

Average $\delta^{15} \mathrm{~N}$ signatures for Mysis diluviana were consistently higher in Kalamalka lake than in Okanagan Lake over the 2 study periods. Within each lake, $\delta^{15} \mathrm{~N}$ values were similar to or slightly less than those of copepods, while being enriched over Daphnia spp. and POM (Table 1), suggesting that mysids were feeding primarily on the latter 2 food types.

Nitrogen isotope signatures for mysids in August 1997 were more similar to those of copepods in Kalamalka Lake (mean difference $=0.9 \% \delta^{15} \mathrm{~N}$ ) than in Okanagan Lake (mean difference $=2.0 \% \delta^{15} \mathrm{~N}$ ). The average mysid $\delta^{15} \mathrm{~N}$ enrichment over Daphnia in Kalamalka Lake (mean difference $=1.9 \%$ ) was also slightly higher than in Okanagan Lake (mean difference = $1.3 \%$ ); therefore, it appears that mysids in Kalamalka Lake may be incorporating more zooplankton in their diet than those in Okanagan Lake.

Mysid $\delta^{15} \mathrm{~N}$ signatures increased with animal size in both lakes, and this increase was significant $(\mathrm{p} \leq 0.004)$ in 3 of 4 comparisons (the exception being Okanagan Lake mysids in August 1997, p = 0.152). However, mysids in Kalamalka Lake exhibited a greater range in isotope signatures between size classes over the 2 sampling periods $\left(2.6 \% \delta^{15} \mathrm{~N}\right)$ than mysids in Okanagan Lake $\left(1.9 \% \delta^{15} \mathrm{~N}\right)$. Across all size classes, Kalamalka Lake mysid $\delta^{15} \mathrm{~N}$ signatures were 1.2 to $3.7 \%$ higher than in Okanagan Lake. Mysid size, however, did not account for the higher nitrogen enrichment in Kalamalka Lake, as the mean sizes of mysids from each size class were within $1.1 \mathrm{~mm}$ of each other (June 1998 collections) (Table 1).

Calculations of mean mysid trophic position based on differences in $\delta^{15} \mathrm{~N}$ between mysids and phytoplankton showed that for both sampling periods, Kalamalka Lake mysids occupied a significantly higher trophic position than those in Okanagan Lake over all size categories ( $p \leq 0.005)$ (Table 1). Estimates of trophic position tended to increase with mysid size category. 


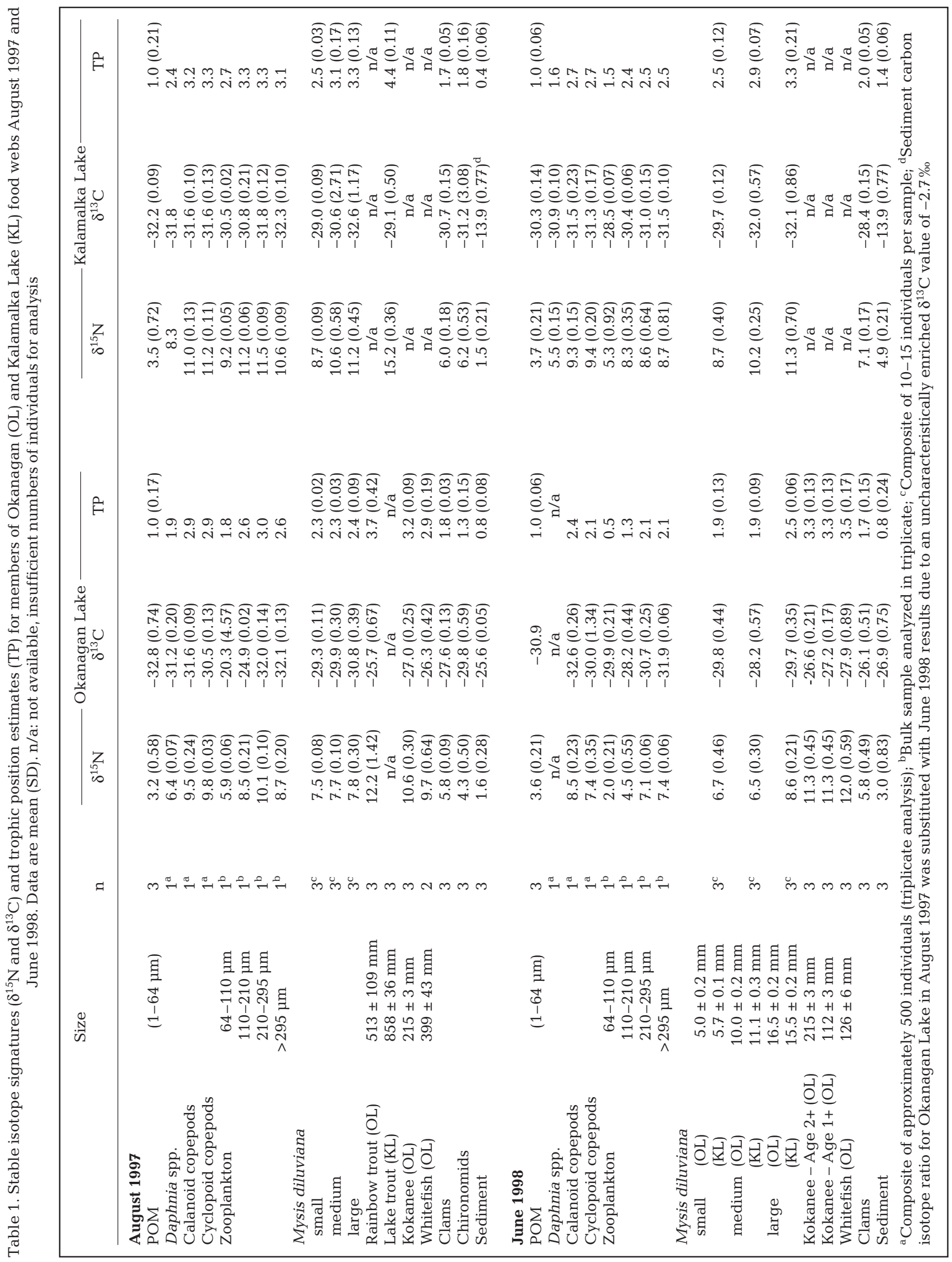


To examine potential food sources for the mysids, carbon isotope signatures in mysids were compared to those for pelagic POM and zooplankton, and benthic sediment material. With the exception of August 1997 collections in Kalamalka Lake, $\delta^{13} \mathrm{C}$ signatures differed significantly between size classes of mysids ( $p \leq 0.010$ ) and tended to become more depleted with increasing mysid size. Mean mysid $\delta^{13} \mathrm{C}$ signatures were similar to, or slightly enriched, over other pelagic zooplankton and POM $\delta^{13} \mathrm{C}$ values, while being more depleted than the sediments (Table 1). For Kalamalka Lake, the August 1997 sediment signatures $\left(-2.7 \pm 0.2 \% \delta^{13} \mathrm{C}\right)$ were not used to determine benthic carbon sources, as these samples had not been acidified, and as such were most likely artificially enriched due to the presence of calcium carbonate in the matrix. Instead, the June 1998 mean sediment values of $-13.9 \pm 0.77 \%$ were used as a surrogate estimate for comparing benthic carbon sources.

Mean $\delta^{13} \mathrm{C}$ signatures from benthic (sediment) and pelagic sources (phyto- and zooplankton) indicated that mysids were assimilating $\geq 70 \%$ of their carbon from pelagic sources, regardless of mysid size class (one exception being medium-sized mysids in Okanagan Lake in June 1998) (Table 2). There was a difference in dietary carbon sources between lakes, however, with Mysis diluviana in Okanagan Lake incorporating more benthic carbon into their diet (mean $=26.0 \%$, range $=4$ to $59 \%$ ) than those in Kalamalka Lake $($ mean $=3.7 \%$, range $=0$ to $13 \%$ ) $($ Table 2$)$.

The fish analyzed from Okanagan Lake were spatially separated from the pelagic zooplankton by both their $\delta^{15} \mathrm{~N}$ and $\delta^{13} \mathrm{C}$ signatures (Table 1 ). Kokanee $\delta^{15} \mathrm{~N}$ values were enriched by up to $4.2 \%$ relative to copepods and Daphnia spp. However, as kokanee $\delta^{13} \mathrm{C}$ values were highly enriched relative to the pelagic zooplankton sampled, it appears that kokanee (and

Table 2. Mysis diluviana. Proportions of benthic and pelagic carbon (\%) assimilated in mysid diet based on mean $\delta^{13} \mathrm{C}$ signatures. Sediment $\delta^{13} \mathrm{C}$ values from August 1997 in Kalamalka Lake were substituted with June 1998 signatures because of highly enriched $\delta^{13} \mathrm{C}$ signatures

\begin{tabular}{|c|c|c|c|c|}
\hline \multirow{2}{*}{$\begin{array}{l}\text { Mysid } \\
\text { size class }\end{array}$} & \multicolumn{2}{|c|}{ Okanagan Lake } & \multicolumn{2}{|c|}{ Kalamalka Lake } \\
\hline & Benthic & Pelagic & Benthic & Pelagic \\
\hline \multicolumn{5}{|c|}{ August 1997} \\
\hline Small & 30 & 70 & 13 & 87 \\
\hline Medium & 19 & 81 & 4 & 96 \\
\hline Large & 4 & 96 & 0 & 100 \\
\hline \multicolumn{5}{|l|}{ June 1998} \\
\hline Small & 21 & 79 & 5 & 95 \\
\hline Medium & 59 & 41 & 0 & 100 \\
\hline Large & 23 & 77 & 0 & 100 \\
\hline
\end{tabular}

whitefish and rainbow trout) were not incorporating carbon from the pelagic zooplankton sampled here. Collections from June 1998 showed that kokanee $\delta^{15} \mathrm{~N}$ signatures were identical for both small and large fish, and $\delta^{13} \mathrm{C}$ values were also similar, suggesting that there is little difference in trophic status or food sources for Okanagan Lake kokanee related to age.

\section{Mysid gut contents}

Nearly all mysid stomachs from both size classes contained zooplankton mandibles, rotifer remains (Keratella spp. and Kellicottia spp.) and detrital material. There was little difference in mandible abundance between lakes for Year 0 mysids, while Year 1 mysids in Okanagan Lake contained $63 \%$ more mandibles per gut than similarly sized mysids in Kalamalka Lake (Table 3). The greater number of prey items in large mysids in Okanagan Lake relative to Kalamalka Lake corresponds to higher zooplankton densities for the sampling stations in Okanagan Lake $\left(19.6 \pm 0.9 \mathrm{l}^{-1}\right)$ relative to Kalamalka Lake $\left(15.8 \pm 0.7 \mathrm{l}^{-1}\right)$ (Table 3$)$. Larger Year 1 mysids contained approximately twice as many mandibles as the smaller Year 0 mysids in both lakes.

Despite lower concentrations of Daphnia spp. in both lakes, their mandibles were found in quantities similar to or higher than those of calanoids and cyclopoids, indicating that mysids were preferentially selecting the larger cladocerans. Depending on the time and mysid age, Diaphanosoma spp. mandibles were found in numbers similar to those of the calanoid mandibles (Table 3) and Bosmina spp. mandibles were low in number or not found. Cyclopoid mandibles were 12 to 14 times more abundant in the guts of larger Year 1 mysids than calanoids in both lakes, reflecting the greater densities of cyclopoids in both lakes.

\section{Mysid clearance rates}

Clearance rates varied with mysid age, prey type and lake (Fig. 1). In Okanagan Lake there was no significant difference in mysid clearance rates on the total zooplankton assemblage or individual taxa between cohorts ( $p \geq 0.058$ ). However, in Kalamalka Lake the average Year 1 mysid clearance rate was significantly higher than that of the Year 0 mysids on the total zooplankton assemblage and for all individual taxa, with the exception of Diaphanasoma spp. ( $\mathrm{p}<0.001)$. In general, mysids from both cohorts had higher clearance rates for cladoceran prey (47 to $467 \mathrm{ml} \mathrm{mysid}^{-1} \mathrm{~h}^{-1}$ ) than copepod prey (9 to $125 \mathrm{ml}$ mysid $^{-1} \mathrm{~h}^{-1}$ ) (Fig. 1). 
Table 3. Mysis diluviana. Zooplankton densities and mandible abundance in gut contents of mysids from Okanagan and Kalamalka Lakes, August 1997 ( $\mathrm{n}=10$ mysids per group). Data are mean (SE)

\begin{tabular}{|c|c|c|c|c|c|c|}
\hline \multirow[t]{3}{*}{ Prey type } & \multicolumn{2}{|c|}{ Zooplankton density (ind. $\mathrm{l}^{-1}$ ) } & \multicolumn{4}{|c|}{ Zooplankton mandibles (no. per mysid) } \\
\hline & \multirow[t]{2}{*}{ Okanagan Lake } & \multirow[t]{2}{*}{ Kalamalka Lake } & \multicolumn{2}{|c|}{ Okanagan Lake } & \multicolumn{2}{|c|}{ Kalamalka Lake } \\
\hline & & & Year 0 & Year 1 & Year 0 & Year 1 \\
\hline Calanoids & $5.5(0.4)$ & $2.5(0.3)$ & $0.3(0.4)$ & $1.1(0.9)$ & $2.5(0.8)$ & $1.3(2.0)$ \\
\hline Cyclopoids & $12.2(0.8)$ & $12.2(0.6)$ & $0.3(0.2)$ & $12.9(3.3)$ & $0.9(0.9)$ & $17.7(4.6)$ \\
\hline Daphnia spp. & $1.7(0.2)$ & $0.4(0.1)$ & $5.6(1.7)$ & $37.5(5.5)$ & $0.8(0.6)$ & $9.7(2.9)$ \\
\hline Diaphanasoma spp. & $0.2(0.02)$ & $0.5(0.07)$ & $0.0(0.0)$ & $0.0(0.0)$ & $3.3(0.8)$ & $2.4(2.5)$ \\
\hline Bosmina spp. & $0.0(0.0)$ & $0.2(0.04)$ & $0.0(0.0)$ & $0.0(0.0)$ & $0.0(0.0)$ & $0.5(0.4)$ \\
\hline Total & $19.6(0.9)$ & $15.8(0.7)$ & $6.1(1.8)$ & $51.5(6.4)$ & $7.4(1.5)$ & $31.6(6.4)$ \\
\hline Mean mysid length (mm) & & & $6.5(0.2)$ & $15.4(0.4)$ & $7.5(0.2)$ & $15.4(0.2)$ \\
\hline
\end{tabular}

Between-lake comparisons showed that average Year 0 mysid clearance rates on the total available zooplankton assemblage were significantly higher in Okanagan Lake than in Kalamalka Lake ( $<$ 0.001) (Fig. 1a). For


Fig. 1. Mysis diluviana. Clearance rates $(F)$ on zooplankton (mean $\pm \mathrm{SE}$ ) for the (a) Year 0 and (b) Year 1 cohorts in Okanagan (OL) and Kalamalka Lakes (KL) in June and August 1997. Copepods and nauplii were present in all 6 trials in both lakes, while Daphnia were present for 3 trials in both lakes the larger Year 1 mysids, however, clearance rates were not significantly different between lakes $(\mathrm{p}=0.299)$ (Fig. 1b). Mysid size ranges within each cohort during the study (mean lengths of Year $0=5.0$ to $7.1 \mathrm{~mm}$, Year $1=14.1$ to $16.5 \mathrm{~mm}$ ) did not appear to influence clearance rates. No significant relationships were found between average clearance rates on the total zooplankton assemblage and mean body length, with either the Year 0 (ANOVA, $\left.r^{2}=0.07, p=0.40\right)$ or Year 1 mysid cohorts $\left(\mathrm{r}^{2}=0.08, \mathrm{p}=0.20 ; \mathrm{n}=12\right.$ for both cohorts).

\section{DISCUSSION}

Although Mysis diluviana in both Okanagan and Kalamalka Lakes originate from the same Kootenay Lake, British Columbia, stock, the mysid populations in these 2 lakes appear to occupy different trophic levels. This plasticity in food selection has allowed the species to colonize many large oligotrophic lakes in North America and northern Europe (Lasenby et al. 1986). We hypothesized that mysids in Okanagan Lake should have been incorporating a greater proportion of zooplankton into their diet relative to mysids in Kalamalka Lake, which contained a much larger kokanee population. Examination of mysid gut contents and clearance rate experiments demonstrated that $M$. diluviana in both lakes were consuming similar proportions of zooplankton prey. Stable isotope analysis revealed that Okanagan mysids did not occupy an elevated trophic position relative to those from Kalamalka Lake. 


\section{Trophic position of M. diluviana}

Trophic position estimates suggested that adult mysids tended to occupy primary and secondary consumer roles in the planktonic food webs of Okanagan and Kalamalka Lakes, respectively. However, stable isotope analyses did not support the original hypothesis that the trophic position of mysids in Okanagan Lake is higher; rather, the mysids' higher trophic position in Kalamalka Lake indicated that their diet contained a greater proportion of zooplankton than the diet of those in Okanagan Lake.

Estimates of trophic position for mysids were determined as the difference in $\delta^{15} \mathrm{~N}$ signatures in mysids relative to POM (1 to $64 \mu \mathrm{m}$ size range), which is assumed to be predominantly composed of phytoplankton (Kling et al. 1992, Keough et al. 1996). The estimated error variance in trophic position estimates in lake food webs is very small $( \pm 0.045 \mathrm{TP})$ when primary consumers such as mussels or clams are used as a baseline $\delta^{15} \mathrm{~N}$ signature compared to primary producers ( \pm 0.16 TP) (Vander Zanden \& Rasmussen 2001). However, primary producers were used as baseline trophic position estimates in the present study due to the lack of long-lived primary consumers in the deep pelagic zones. Although clams were available from the littoral zone of both Okanagan and Kalamalka Lakes, the potential for distinct isotopic ratios between littoral and pelagic consumers (France 1995, Keough et al. 1996, Fry 1999) precluded their use for estimating primary producer isotope signatures in the pelagic food web.

Elevated trophic positions for mysids in Kalamalka Lake correspond to higher $\delta^{15} \mathrm{~N}$ signatures of sediments in this lake. However, it is not clear to what extent mysids were incorporating the nitrogen-enriched sediments in Kalamalka Lake, as carbon mixing model results suggest Kalamalka Lake mysids were obtaining the majority of their nutrition from pelagic sources. Trophic position estimates for mysids were not calculated using sediment $\delta^{15} \mathrm{~N}$ ratios as a baseline because benthic nitrogen sources for mysids would include a mixture of primary and secondary productivity.

Although differences in nitrogen isotope ratios between predator and prey range from +3 to $5 \%$ (Peterson \& Fry 1987), the value of $3.4 \%$ ofrom Minagawa \& Wada (1984) was used to calculate mysid trophic position. A literature review of the change in $\delta^{15} \mathrm{~N}$ values for 20 species between consumers and prey in 22 studies revealed an overall enrichment of $3.46 \pm 0.23 \%$ (Vander Zanden \& Rasmussen 2001). This value is also very close to the mean trophic enrichment of $+3.2 \%$ between a frozen cladoceran food source and Neomysis integer in controlled laboratory feeding experiments (Toda \& Wada 1990). In Lake Ontario, a trophic enrichment factor of $2.2 \%$ o $\delta^{15} \mathrm{~N}$ provided the best cor- respondence between observed stable isotope signatures for Mysis diluviana and those expected based on dietary composition and a $100 \%$ nitrogen tissue turnover rate (Johannsson et al. 2001). Our assumed fractionation factor of $3.4 \%$ is higher than that of Lake Ontario mysids; however, the mean trophic enrichment factor between Daphnia spp. and POM in the present study was $+3.3 \pm 0.4 \%$, suggesting that an assumed transfer of $+3.4 \%$ o $\delta^{15} \mathrm{~N}$ between trophic levels was appropriate.

\section{Food sources of Mysis diluviana}

There is isotopic evidence that mysids are feeding on different food sources according to their stage in life. With the exception of Okanagan Lake in August 1997, large mysids were enriched in $\delta^{15} \mathrm{~N}$ relative to small mysids by approximately $2 \%$, which resulted in an elevated trophic position estimate for large mysids of 0.6 to 0.8 . This nitrogen isotope enrichment in the larger mysids suggests an ontogenetic shift in diet to incorporate a greater proportion of the more enriched zooplankton food source relative to POM. Similar ontogenetic shifts in nitrogen isotopic enrichment for Mysis diluviana have been reported in eastern North American lakes (Branstrator et al. 2000). Here, seasonal $\delta^{15} \mathrm{~N}$ values also increased by approximately $2 \%$ o (range = 1.7 to $3.1 \%$ ) between small and large mysids, representing an increase in trophic elevation of 0.6 to 0.9 (Branstrator et al. 2000).

Mysid $\delta^{13} \mathrm{C}$ values also indicate a potential shift in food resources with age. The 2-stage mixing model comparing mean pelagic and benthic $\delta^{13} \mathrm{C}$ signatures showed that mysids assimilated most of their carbon from planktonic rather than benthic sources. The relative proportions of more depleted planktonic $\delta^{13} \mathrm{C}$ to more enriched benthic $\delta^{13} \mathrm{C}$ tended to increase with increasing mysid size class, suggesting that the mysids relied more extensively on plankton with increasing age.

Mysis diluviana is omnivorous and may change its diet with seasonal changes in food availability (Johannsson et al. 2001). Gorokhova \& Hansson (1999) demonstrated that for M. mixta and Neomysis integer, different foods with different isotopic ratios give rise to different isotopic composition in the mysid tissue. They also showed that the isotopic composition of different tissues depends on the growth and turnover rate of the tissue. Isotopic ratios in muscle tissue reflected food sources obtained over the previous 6 to $8 \mathrm{wk}$ for $\delta^{15} \mathrm{~N}$ and up to $3 \mathrm{mo}$ for $\delta^{13} \mathrm{C}$. In the present study, we used similarly sized mysids collected at the same time of year and analyzed whole animals from both lakes. We examined gut contents and carried out clearance rate 
experiments to confirm that mysids from both lakes had similar diets at the time of collection. However, seasonal variation may occur and further studies should be undertaken to address this.

Mysids can obtain a substantial portion of their energy from sediments during the daylight hours, when they are not foraging in the pelagic zone (Parker 1980, Johannsson et al. 1994, Leggett 1998). In Okanagan Lake, Mysis diluviana appeared to be obtaining more of its diet from the sediments, as benthic carbon contributed up to $59 \%$ compared to $\leq 13 \%$ in Kalamalka Lake. This does not support the hypothesis that mysids in Okanagan Lake incorporate a greater proportion of zooplankton prey if they outcompete kokanee for zooplankton resources.

Acoustic echograms of mysids in Okanagan Lake from a $150 \mathrm{~m}$ deep station showed that a large portion of the population remained at between 100 and $120 \mathrm{~m}$ during the day (Levy 1991), which would reduce potential feeding time on sediment detrital organic matter. Although mysids in both lakes were restricted to $>50 \mathrm{~m}$ depth after sunrise (Whall 2000), it is not known what proportions of the population were located at the sediment-water interface. Kalamalka Lake mysids may remain higher off the sediments because of the reduced water transparency from the high carbonate levels in the water column. Mysids remain elevated in the water column in the Armstrong Arm region of Okanagan Lake, which has greatly reduced water transparency relative to the main basins (McEachern 1999). As transparency in Kalamalka Lake (as measured by Secchi depth) was 1 to $3 \mathrm{~m}$ lower than in Okanagan Lake during the sampling periods (McEachern 1999), mysids may not have been migrating as deeply in the less transparent Kalamalka Lake, and therefore not incorporating as much sediment detrital matter in their diets.

Mysids were obtained in night-time vertical hauls from $\sim 2 \mathrm{~m}$ off the bottom to the surface. Therefore, if a proportion of the population remained at the sediment-water interface during the nightly migration, they would not have been included in our stable isotope analyses. It is unlikely, however, that these animals would have distinctly different diets, as Johannsson et al. (2001) found no consistent differences in $\delta^{15} \mathrm{~N}$ or $\delta^{13} \mathrm{C}$ isotope ratios for ascending, descending or benthic Mysis diluviana in Lake Ontario.

Lipids of aquatic consumers can be depleted in $\delta^{13} \mathrm{C}$ relative to body tissues, and intensive lipid storage may result in lower $\delta^{13} \mathrm{C}$ signatures than an organism's diet (Gu et al. 1994, 1996, Leggett 1998). In a comparison of lipid-extracted and non-lipid-extracted mysids from Lake Ontario, Leggett (1998) found that the mean $\delta^{13} \mathrm{C}$ of mysids with lipids removed $(-28.9 \pm 0.58)$ was enriched relative to non-treated mysids $(-32.2 \pm 0.67)$.
However, Adare \& Lasenby (1994) found that between several lakes spanning a range of trophic states, similarly sized mysids had similar lipid contents. As mean size of mysids in Okanagan and Kalamalka Lakes sampled for stable isotopes was within $1 \mathrm{~mm}$ of each other (Table 1), we do not expect significant differences in lipid-related carbon depletion between them. Smyntek et al. (2007) established a correction factor for $\delta^{13} \mathrm{C}$ enrichment in lake zooplankton based on their $\mathrm{C} / \mathrm{N}$ ratios. In the future, species-specific $\delta^{13} \mathrm{C}$ value lipidcorrection factors based on measured $\mathrm{C} / \mathrm{N}$ ratios (as established for mysids by Leggett 1998) may be necessary for all members of the food web being studied.

The lack of increase in $\delta^{15} \mathrm{~N}$ signatures in mysids relative to copepods is puzzling. Although selectivity coefficients have shown that cladocerans are selected over copepods, mysids readily consumed copepods in experimental chambers and in gut content analysis in the present study. Toda \& Wada (1990) also found that mysid $\delta^{15} \mathrm{~N}$ signatures were on average $\sim 1 \%$ lower than those of zooplankton and $\sim 3.7 \%$ enriched relative to POM (mostly phytoplankton), despite being an assumed predator on the zooplankton. The authors suggested that zooplankton did not constitute a major source of the mysid diet, but rather that mysid $\delta^{15} \mathrm{~N}$ signatures tracked the seasonal changes in POM more closely. Branstrator et al. (2000) also found that fractionation factors (i.e. trophic elevations) for Mysis diluviana relative to bulk zooplankton samples were $<1$ (range $=0.1$ to 0.89 ), implying that for their study lakes in eastern North America, mysids had diets similar to that of bulk zooplankton.

Another potential food source for Mysis diluviana are benthic invertebrates. Due to difficulties in recovering benthos from the deep mysid sampling stations (generally $>150 \mathrm{~m}$ ), representative chironomid samples were obtained from shallower littoral regions $(<40 \mathrm{~m})$ in August 1997. Mysid $\delta^{15} \mathrm{~N}$ ratios were enriched by 3.2 to $5.0 \%$ relative to chironomids, while $\delta^{13} \mathrm{C}$ values were nearly equivalent to those of mysids (Table 1), suggesting that chironomids may also make up part of the diet of $M$. diluviana in the 2 lakes. Although chironomid mandibles were not found in the guts of the mysids examined, this may have been due to the relatively small sample size $(n=10$ per lake) or the result of rapid gut passage times (generally between 1 and $6 \mathrm{~h}$ for M. diluviana; Chipps 1998) and the fact that the animals were retrieved several hours after migrating off the lake bottom and feeding in the metalimnion.

Interactions between mysids and kokanee

Stable isotopes suggest that in Okanagan Lake there may be more separation in the trophic and feeding 
relationships between the deep-water mysids and kokanee than previously thought. Based on $\delta^{15} \mathrm{~N}$ values, kokanee salmon are occupying a higher trophic position (3.2 to 3.3) than Mysis diluviana (1.9 to 2.5). In addition, kokanee $\delta^{13} \mathrm{C}$ values are enriched relative to pelagic zooplankton in Okanagan Lake by more than the mean trophic enrichment factor of $0.8 \%$ observed for aquatic consumers (herbivores excluded; Vander Zanden \& Rasmussen 2001). Spatial separation within the lake can lead to differences in carbon signatures: $\delta^{13} \mathrm{C}$ signatures in both POM and zooplankton from the littoral zone can be enriched relative to those in the pelagic zone (Fry 1991). This separation in $\delta^{13} \mathrm{C}$ was found for alewife Alosa pseudoharengus in Lake Superior; Keough et al. (1996) found that the $\delta^{13} \mathrm{C}$ signature of the alewife was more closely linked with the enriched carbon isotopes found in the shallow wetland ecosystem than the more ${ }^{13} \mathrm{C}$-depleted pelagic system, suggesting that alewife may have spent more time feeding in the shallower regions of the lake. Therefore, kokanee, which are primarily planktivorous (Foerster 1968), may be consuming zooplankton that are spatially distinct from the pelagic zooplankton consumed by the deep-water mysids. Evidence from stable carbon isotope studies with $\delta^{13} \mathrm{C}$ has indicated that dual trophic pathways from benthic and pelagic production to consumer biomass can be important in lakes (Vadeboncoeur et al. 2002, Vander Zanden \& Vadeboncoeur 2002). It is possible that both benthic and pelagic pathways play a significant role in kokanee production in Okanagan Lake.

\section{Supporting evidence for mysid predatory capabilities}

Clearance rates represent the ability of a predator to remove prey items from its environment within a given amount of time. Higher clearance rates for particular prey items reflect a more efficient predatory capacity and imply selection pressure on those prey species. In both study lakes, clearance rates were highest for cladocerans and copepod nauplii, followed by adult copepods. Bowers \& Vanderploeg (1982) reported a similar order of preference for mysids feeding on a natural zooplankton assemblage from Lake Michigan, where cladocerans are preferred, followed by copepod copepodites and nauplii, and lastly adult copepods. Adult mysid clearance rates for copepods in the present study were generally similar to those found in other central and western North American lakes (Table 4). Clearance rates on cladocerans however, were markedly lower than those found for mysids in Lake Michigan and central Ontario lakes. The significantly higher clearance rates for larger mysids $>1$ yr old over smaller mysids $<1$ yr old in Kalamalka Lake supports the isotopic evidence for increased predatory capacity with size. Further support comes from gut contents, where larger mysids $>1$ yr old from both study lakes contained twice the number of zooplankton mandibles in their guts as mysids < 1 yr old (Table 3).

The variability in clearance rates between the present and other studies suggests that the ability of a mysid to search for, secure and ingest its prey will be influenced by lake-specific factors such as temperature, light availability, productivity and prey assemblage (Nero \& Sprules 1986, Smokorowski 1998). The relatively low variability surrounding the clearance rate estimates for both lakes over 2 sampling months indicates that mysid populations within each lake have generally consistent feeding preferences.

By conducting clearance rate experiments and gut content analysis concurrently with nitrogen and carbon isotope analyses, the present study has demonstrated the advantages of using multiple lines of evidence in assessing the diets of omnivorous zooplankton such as Mysis diluviana. Basing trophic role estimates only on clearance rate data or gut contents would have overestimated the contribution of zooplankton to mysid diets, without being able to quantify the amount of primary production being assimilated. Likewise, caution must be used when interpreting stable isotope data, because signatures can be confounded by physiological and environmental factors; temporal trends in isotopic ratios of consumers can arise due to differences in animal growth rates, lipid content, degree of fractionation and seasonal changes

Table 4. Mysis diluviana. Comparison of adult mysid clearance rates $\left(\mathrm{ml} \mathrm{mysid}^{-1} \mathrm{~h}^{-1}\right)$ between the present study and selected North American lakes

\begin{tabular}{|lcccccll}
\hline & \multirow{2}{*}{ Calanoids } & Cyclopoids & Copepod & Daphnia Diaphanasoma & Source \\
& & & nauplii & spp. & spp. & \\
\hline Okanagan and Kalamalka Lakes & $22-116$ & $28-101$ & $8-124$ & $47-181$ & $251-467$ & This study \\
Kootenay Lake & $50-110$ & $50-120$ & - & $10-80$ & $110-232$ & Smokorowski (1998) \\
Central Ontario lakes & $42-110$ & - & $75-167$ & $392-801$ & $452-1019$ & Nero \& Sprules (1986) \\
Lake Michigan & $40-113$ & $0-339$ & 294 & $870^{\mathrm{a}}$ & - & Bowers \& Vanderploeg (1982) \\
Flathead Lake & - & $61-133$ & - & $221-244$ & - & Spencer et al. (1999) \\
acombined Cladocera (Daphnia and Bosmina) & & & & & \\
\hline
\end{tabular}


in isotope ratios of primary producers (Leggett 1998, Johannsson et al. 2001, Vander Zanden \& Rasmussen 2001). In the present study, stable isotopes demonstrated that mysids were not occupying the same trophic position in both lakes, but clearance rate and gut content data confirmed the importance of dietary food sources, such as copepods, that were not reflected in the isotope signatures of the mysids.

In summary, our hypothesis that Mysis diluviana in Okanagan Lake should be occupying a relatively higher trophic position than mysids in Kalamalka Lake was not supported, since stable isotopes indicated that Kalamalka Lake mysids were acting as secondary consumers or true carnivores, whereas Okanagan Lake mysids were closer to primary consumers, incorporating a greater proportion of their energy from primary producers. These results demonstrate the benefits of using both assimilated nutrient content (i.e. stable isotope analysis) and direct dietary assessments (i.e. in situ feeding experiments and gut content analysis) in establishing trophic roles for omnivorous animals.

Acknowledgements. The authors thank the BC Habitat Conservation Fund for funding, the BC Ministry of Environment Lands and Parks for logistical support (including L. McEachern, G. Young, D. Smith, D. Sebastian and B. Shepherd) and L. Rudstam and 2 anonymous reviewers who provided valuable comments on this manuscript.

\section{LITERATURE CITED}

Adare K, Lasenby DC (1994) Seasonal changes in the total lipid content of the opossum shrimp, Mysis relicta (Malacostraca: Mysidacea). Can J Fish Aquat Sci 51:1935-1941

Andrusak H (2000) Mysis relicta in Okanagan Lake: a summary of their numbers, distribution, and results of experimental trawl fishing, 1999. In: Andrusak H, Sebastian D, McGregor I, Matthews S and others (eds) Results of implementation of the Okanagan Lake Action Plan. Year 4 (1999) Report. Fisheries Project Report No. RD 83. Fisheries Management Branch, Ministry of Agriculture, Food and Fisheries, Vancouver, BC, p 278-312

Ashley K, Thompson L, Lasenby DC, McEachern L, Smokorowski K, Sebastian D (1997) Restoration of an interior lake ecosystem: the Kootenay Lake fertilization experiment. Water Qual Res J Canada 32:295-323

Ashley K, Shepherd B, Sebastian D, Thompson L and others (1998) Okanagan Lake Action Plan. Year 1 (1996-97) and Year 2 (1997-98) Report. Fisheries Project Report No. RD 73. Fisheries Management Branch, Ministry of Agriculture, Food and Fisheries, Vancouver, BC

Audzijonyte A, Väinölä R (2005) Diversity and distributions of circumpolar fresh- and brackish-water Mysis (Crustacea: Mysidacea): descriptions of $M$. relicta Lovén, 1862, $M$. salemaai n. sp., M. segerstralei n. sp. and M. diluviana n. sp., based on molecular and morphological characters. Hydrobiologia 544:89-141

Beattie W, Clancey P (1991) Effects of Mysis relicta on the zooplankton community and kokanee population of Flathead Lake, Montana. Am Fish Soc Symp 9:39-48
Bowers J, Vanderploeg H (1982) In situ predatory behaviour of Mysis relicta in Lake Michigan. Hydrobiologia 93:121-131

Bowles E, Rieman B, Mauser G, Bennett D (1991) Effects of introductions of Mysis relicta on fisheries in northern Idaho. Am Fish Soc Symp 9:65-74

Branstrator DK, Cabana G, Mazumder A, Rasmussen JB (2000) Measuring life history omnivory in the opossum shrimp, Mysis relicta, with stable nitogen isotopes. Limnol Oceanogr 45:463-467

Cabana G, Rasmussen JB (1994) Modelling food chain structure and contaminant bioaccumulation using stable nitrogen isotopes. Nature 372:255-257

Chipps SR (1998) Temperature-dependent consumption and gut-residence time in the opossum shrimp Mysis relicta. J Plankton Res 20:2401-2411

Estep M, Vigg S (1985) Stable carbon and nitrogen isotope tracers of trophic dynamics in natural populations and fisheries of the Lahontan Lake System, Nevada. Can J Fish Aquat Sci 42:1712-1779

Foerster R (1968) The sockeye salmon (Oncorhynchus nerka). Bull Fish Res Board Can 162

France R (1995) Differentiation between littoral and pelagic food webs in lakes using stable carbon isotopes. Limnol Oceanogr 40:1310-1313

> Fry B (1991) Stable isotope diagrams of freshwater food webs. Ecology 72:2293-2297

> Fry B (1999) Using stable isotopes to monitor watershed influences on aquatic trophodynamics. Can J Fish Aquat Sci 56:2167-2171

Gorokhova E, Hansson S (1999) An experimental study on variations in stable carbon and nitrogen isotope fractionation during growth of Mysis mixta and Neomysis integer. Can J Fish Aquat Sci 56:2203-2210

> Gu B, Schell D, Alexander V (1994) Stable carbon and nitrogen isotopic analysis of the plankton food web in a subarctic lake. Can J Fish Aquat Sci 51:1338-1344

> Gu B, Schelske C, Hoyer M (1996) Stable isotopes of carbon and nitrogen as indicators of diet and trophic structure of the fish community in a shallow hypereutrophic lake. J Fish Biol 49:1233-1243

> Johannsson OE, Rudstam LG, Lasenby DC (1994) Mysis relicta: assessment of metalimnetic feeding and implications for competition with fish in lakes Ontario and Michigan. Can J Fish Aquat Sci 51:2591-2602

> Johannsson OE, Leggett MF, Rudstam LG, Servos MR, Mohammadian MA, Gal G, Dermott RM, Hesslein RH (2001) Diet of Mysis relicta in Lake Ontario as revealed by stable isotope and gut content analysis. Can J Fish Aquat Sci 58:1975-1986

Keough J, Sierszen JM, Hagley C (1996) Analysis of a Lake Superior coastal food web with stable isotope techniques. Limnol Oceanogr 41:136-146

- Kling G, Fry B, O'Brien WJ (1992) Stable isotopes and planktonic trophic structure in Arctic lakes. Ecology 73:561-566

Lasenby DC, Shi Y (2004) Changes in the elemental composition of the stomach contents of the opossum shrimp Mysis relicta during diel vertical migration. Can J Zool 82:525-528

Lasenby DC, Northcote T, Fürst M (1986) Theory, practice and effects of Mysis relicta introductions to North American and Scandinavian lakes. Can J Fish Aquat Sci 43: $1277-1284$

Leggett MF (1998) Food-web dynamics of Lake Ontario as determined by carbon and nitrogen stable isotope analysis. PhD thesis, University of Waterloo, ON

> Levy D (1991) Acoustic analysis of diel vertical migration behaviour of Mysis relicta and kokanee (Oncorhynchus 
nerka) within Okanagan Lake, British Columbia. Can J Fish Aquat Sci 48:67-72

Martinez P, Bergersen E (1991) Interactions of zooplankton, Mysis relicta and kokanees in Lake Granby, Colorado. Am Fish Soc Symp 9:49-64

McEachern L (1999) Trends in physical and chemical limnology: seasonal variation in zooplankton communities of Okanagan Lake and Kalamalka Lake, 1996 through 1998. In: Ashley K, McGregor I, Shepherd B, Sebastian D and others (eds) Okanagan Lake Action Plan. Year 3 (1998) Report. Fisheries Project Report No. RD 78. Fisheries Management Branch, Ministry of Fisheries, Vancouver, BC, p 101-126

Minagawa M, Wada E (1984) Stepwise enrichment of ${ }^{15} \mathrm{~N}$ along food chains: further evidence and the relation between $\delta^{15} \mathrm{~N}$ and animal age. Geochim Cosmochim Acta 48: $1135-1140$

Morgan M, Threlkeld S, Goldman C (1978) Impact of the introduction of kokanee (Oncorhynchus nerka) and opossum shrimp (Mysis relicta) on a subalpine lake. J Fish Res Board Can 35:1572-1579

Naesje T, Saksgard R, Jensen A, Sandlund O (2003) Life history, habitat utilisation, and biomass of introduced Mysis relicta. Limnologica 33:236-257

Nero R, Sprules G (1986) Predation by three glacial opportunists on natural zooplankton communities. Can J Fish Aquat Sci 64:57-64

Parker J (1980) Predation by Mysis relicta on Pontoporeia hoyi: a food chain link of potential importance in the Great Lakes. J Great Lakes Res 6:164-166

Peterson BJ, Fry B (1987) Stable isotopes in ecosystem studies. Annu Rev Ecol Syst 18:293-320

Post DM (2002) Using stable isotopes to estimate trophic position: models, methods, and assumptions. Ecology 83: $703-718$

Sebastian DC, Scholten G (1998) Okanagan Lake kokanee abundance, size and age structure based on trawl and acoustic surveys: 1988-97. In: Ashley K, Shepherd B, Sebastian D, Thompson L and others (eds) Okanagan Lake Action Plan. Year 1 (1996-97) and Year 2 (1997-98) Report. Fisheries Project Report No. RD 73. Fisheries

Submitted: April 4, 2008; Accepted: April 17, 2009
Management Branch, Ministry of Fisheries, Vancouver, BC, p 64-74

Smokorowski K (1998) The response of the freshwater shrimp, Mysis relicta, to the partial fertilization of Kootenay Lake, British Columbia. PhD thesis, Trent University, Peterborough, ON

Smyntek PM, Teece MA, Schulz KL, Thackeray SJ (2007) A standard protocol for stable isotope analysis of zooplankton in aquatic food web research using mass balance correction models. Limnol Oceanogr 52:2135-2146

Spencer CN, Potter DS, Bukantis RT, Stanford JA (1999) Impact of predation by Mysis relicta on zooplankton in Flathead Lake, Montana, USA. J Plankton Res 21:51-64

Sprules G, Bowerman J (1988) Omnivory and food chain length in zooplankton food webs. Ecology 69:418-426

> Toda H, Wada E (1990) Use of ${ }^{15} \mathrm{~N} /{ }^{14} \mathrm{~N}$ ratios to evaluate the food source of the mysid, Neomysis intermedia Czerniawsky, in a eutrophic lake in Japan. Hydrobiologia 194: $85-90$

> Vadeboncoeur Y, Vander Zanden MJ, Lodge DM (2002) Putting the lake back together: reintegrating benthic pathways into lake food web models. Bioscience 52:44-54

- Vander Zanden MJ, Rasmussen JB (1996) A trophic position model of pelagic food webs: impact on contaminant bioaccumulation in lake trout. Ecol Monogr 66:451-477

Vander Zanden MJ, Rasmussen JB (2001) Variation in $\delta^{15} \mathrm{~N}$ and $\delta^{13} \mathrm{C}$ trophic fractionation: implications for aquatic food web studies. Limnol Oceanogr 46:2061-2066

> Vander Zanden MJ, Vadeboncoeur Y (2002) Fishes as integrators of benthic and pelagic food webs in lakes. Ecology 83:2152-2156

- Vander Zanden MJ, Cabana G, Rasmussen JB (1997) Comparing trophic position of freshwater fish calculated using stable nitrogen isotope ratios $\left(\delta^{15} \mathrm{~N}\right)$ and literature dietary data. Can J Fish Aquat Sci 54:1142-1158

Wada E, Kabaya Y, Kurihara Y (1993) Stable isotopic structure of aquatic systems. J Biosci 18:483-499

Whall JD (2000) Comparison of the trophic role of the freshwater shrimp, Mysis relicta, in two Okanagan Valley Lakes, British Columbia. MSc thesis, Trent University, Peterborough, ON

Proofs received from author(s): May 26, 2009 